Mr. O'Hea must, however, have more facts which enable him to deny the use of an insect's eyes for vision in the face of all the work of Lord Avebury, Plateau, Forel, and many others.

As for Arachnida, an immense number of examples could be quoted as indicating power of vision. The following are obvious (and are cases where " convection currents " are definitely excluded) :

A male Attid will start to dance before the female, though a glass partition separate them, and he turns his head to watch her as she moves.

I have at present two specimens of Lycosa Narbonensis, which, when out of their burrows, will dart back when a sudden movement is made near them, that is within about three yards. (They are always under glass, so that convection currents will explain nothing.) A slow approach, as with the fly, does not disturb them.

It seems to me that, in testing,Commander Hilton Young's hypothesis, we cannot assume the absence of insect vision on such slender evidence as that brought forward by Mr. O'Hea. We must either experiment with species which are known to possess absolutely no power of sight, or obliterate the eyes with a varnish, and then see how the insect behaves in the neighbourhood of a solid body.

G. H. LOCKET.

Salmon's Cross, Reigate, Surrey, April I5.

\section{Science and Economics.}

PROF. SODDY is an eminent chemist and physicist, and it is consistent with his own investigations that he should seek for the " natural fundamental basis of the economic system under which we perish" (NATURe, April r 4 , p. 497). If the natural basis of the system be such as to cause us to perish, the object of a re-examination is, perhaps, to alter Nature and reconstruct de novo. Or, does Prof. Soddy mean that there are natural economic laws of which we are, as yet, not aware, and for which we should search? We know, however, that nineteenth-century economists enunciated natural laws of economics such as competition (survival of the fit) and supply and demand (action and reaction). These laws, nevertheless, were not " natural " to economics ; they were adapted from Nature, as then expounded, and applied artificially by the governments in certain countries.

Prof. Soddy now says, and with some reason, that the present economic system is an offence against common sense. It seems then that the natural obvious truths of the nineteenth century as interpreted economically are, in this century, both unscientific and senseless. Many no doubt will agree with him that the complex modern financial system which evolved through several centuries pari passu with science, and admirably served to stimulate, restrain, and direct the desires and ambitions of an imperfect human race, does not function as responsively as it did. Age may be the cause; it has not renewed itself by new forms of thought as has science. But, whatever the cause, one ventures to disagree with Prof. Soddy when he says that no one pretends to understand the system. This is true only as one might say " no one pretends to understand the "atomic" theory": a few do-that is, those who conduct the operations. Certain axioms hold good until new conditions are introduced; but it is somewhat easier, one would think, to find the formulæ necessary to control operations under new conditions in a laboratory than in the world of human affairs. In the former, mathematics are at hand, but of what assistance are these scientific methods in dealing with complex and unequally developed human beings whose conflicting desires and opinions cannot be mathematically computed and resolved by formulæ?
Again, Prof. Soddy's assertion that the production of wealth is now "a relatively finished science" has a ring of finality hitherto unassociated with science. Many civilisations have shown evidences of great wealth, and its production is always a finished science at any time in an epoch, though relatively so to another. In our own day the need for human labour has not yet been entirely eliminated. It is even less probable that the distribution of wealth will ever become a finished science-at least, until "Earth's last picture is painted." Were the dispensers of credit (whether by patronage or " democratic control ") to achieve a temporary perfection in adjusting the desires and deserts of the social hierarchy even in regard to material things, the mere force of individuality in human beings would upset the balance in time, and the fact of evolution makes this event inevitable, as history shows. There may be a science of the distribution of wealth, and, if so, it is probably associated with the science of government, an art in which rulers and princes of earlier times were especially trained; but one must conclude that its principles are not those of applied physics, for mankind cannot be controlled, transmuted, and led so rapidly and readily on the path of evolution as can the "elements" in the physicist's laboratory.

The ultimate basis of credit in any age is character and ability, on which have been founded the Codes of Laws and social formulie of all great civilisations from the earliest Laws of Manu. It may be as well, therefore, for the preservation of our modern knowledge, that the system by which "tokens of wealth" are distributed should not be radically changed until character is once more clearly defined and appreciated by all classes.

Oakley House, Bloomsbury Street London, W.C.I, April r6.

\section{Effect of Plant Extracts on Blood Sugar. (By CABLE.)}

In the early days of my investigations in connexion with insulin, I predicted that whenever glycogen occurred in Nature an insulin-like substance would also be found. Putting this theory to the test, I obtained positive results first with clam tissue, and later with yeast. This result was obtained during the latter part of January. In the light of this latter result, my mode of reasoning was changed. If yeast contains an insulin-like hormone, other plants may also contain it. Extracts of tissue of a variety of the higher plants were, therefore, prepared, and the effect of subcutaneous injection of these extracts upon the blood sugar of the normal rabbit was ascertained. The effect of certain plant extracts upon the blood sugar of depancreated dogs was also studied. Extracts made from onion tops, onion roots, barley roots and sprouted grain, green wheat leaves, bean tops, and lettuce were found to produce marked hyperglycæmia in normal rabbits. The day following the administration of an extract of green onion tops to a depancreated dog with a blood sugar of 0.190 per cent., a blood sugar of o.ogo per cent. was observed. The results of this investigation were communicated to the Society for Experimental Biology and Medicine at the meeting in New York City on March 2I, when I suggested the name "Glucokinin " for this new plant hormone. Since that date I notice in NATURE of March ro a letter by Messrs. Winter and Smith stating that they have obtained positive results with yeast extracts. These authors would, therefore, share coincident priority with me in this particular.

J. B. COLLIP.

Biochemical Laboratory, University of Alberta, April 2r.

NO. 279 I, VOL. I I I] 